\title{
Evaluating the library director
}

\author{
By Mike Simons \\ Reference Librarian \\ The University of Nevada, Reno
}

\author{
and Anne Amaral
}

Monograph Cataloger

The University of Nevada, Reno

\section{A survey instrument that allows for a formal review.}

$\mathbf{H}$ ow does the staff of an academic library evaluate the performance of its director? Collegial governance calls for periodic review of the library administration by library faculty, but there is little in the literature that describes how this should be done. ${ }^{1}$ Ideally, the process should provide a formal line of communication that allows library staff to give feedback to the director and provide positive reinforcement and constructive criticism. A number of library directors see periodic formal review as a way to provide themselves with genuine help and a healthy exchange of ideas. Such reviews require a director who is personally and professionally secure, and a process that allows openness but protects both staff and director from acrimonious exchanges. What follows is one library's approach to the evaluation of the director.

At the University of Nevada-Reno, library bylaws require library faculty to evaluate the director at least once every four years. They specify that the evaluation shall be of the individual performance of the director, not of the performance of the library as a unit. Our bylaws establish two elected committees, a four-member Personnel Committee and a three-member Budget and Planning Committee, who are charged with various duties including conducting an evaluation of the director in

\footnotetext{
${ }^{\text {IT }}$ The most useful work we found was in Association of Research Libraries, Office of Management Studies, Executive Review in ARL Libraries, SPEC Kit \#72 (Washington, D.C.: ARL/OMS, 1981). Also published as an ERIC document (ED 214532 ).
}

consultation with the library faculty. Despite the bylaws, the last such evaluation took place in 1976 . For one reason or another, the committees had continually postponed doing another. Two years ago, our library committees decided that the main reason evaluations had not been done was because no established evaluation procedure had been developed. Every year new committees were faced with what seemed an overwhelming, timeconsuming task. We decided to devote a number of months to developing the evaluation process and do the actual evaluation the next year.

Our first step was to develop a survey instrument that would enable staff to rate and give their written opinions of the director's leadership, communication and professional development. The rating would be confidential; no one would be required to sign the survey questionnaire. Also it would survey only professional library faculty opinion, which would be consistent with collegial review. We decided to follow the survey with interviews of all professional staff who wished to participate because we felt many busy staff members wouldn't take the time to write a critique, but would respond in a one-to-one interview (survey and interview questions are given at the end of this article). Our staff had only 23 professionals at that time, so each of the seven committee members would have to interview only three or four staff members. In an interview situation it would be possible to ask follow-up questions and to probe for explanations and examples of specific perceptions. During an interview it would also be possible to gauge the intensity of someone's position on a specific matter. 
The interview response could not, obviously, be completely confidential, but the interviewers were asked not to attach names to the responses they gathered. We hoped that through the written survey and the interviews we would accumulate candid opinion from a diverse group of librarians. We felt, however, that it would be unfair to simply deposit the responses on the director's desk. That would be like presenting him with 23 anonymous letters. We decided instead to synthesize the faculty responses into a summary statement which the committee members would sign. We hoped in this way to encourage a wide response but still produce an evaluation for which named persons would be accountable. The evaluation report would consist of an overall rating based on the last question of the written survey, a summary of the responses from the questionnaire and the interviews, and a statistical summary of the rating scale survey.

The question of whether the final evaluation should be confidential or public information was considered. After discussion with the university faculty senate chairman and the university president, we decided to follow university and general personnel practice and consider the evaluation to be a confidential document.

The actual evaluation began in the fall of 1987 and was completed in June 1988 . Twenty staff members returned the written questionnaire and 18 took part in the interviews. Copies of the evaluation went to the library director and the university president as required in our library bylaws; all other copies were destroyed. Copies of the survey instrument and the interview questions were sent to library archives to be preserved.

How do we rate our evaluation process? We believe it was successful. The written survey was valuable in eliciting library faculty input. In some areas there was a wide diversity of opinion that was impossible to summarize, but there were also a number of areas in which a majority of responders agreed. The wide diversity of opinion may have been caused by the different relationships between various staff and the director; that is, those working directly under the director had a different perspective than those who reported to department supervisors. The survey instrument might be improved by asking responders to indicate if they are supervisors.

The oral interviews were valuable in eliciting comments, but incorporating them into the evaluation summary posed a bit of a problem. It was impossible in most cases to use direct quotes and still maintain the confidentiality of the person being quoted. Abstracting the quotes into a summary, however, caused much of the immediacy and intensity of the comments to be lost. The committees opted for confidentiality but were not totally happy with the result.

One of the most difficult aspects of the evaluation was to include criticism that could be perceived as constructive. The praises and accolades were easy, even fun, to write, but the criticisms required many rewrites. We persevered, however, because we all felt that making something positive out of criticism should be one of the outcomes of collegial governance.

Overall, we believe the process worked. It allowed the staff to applaud the director's strengths and offer constructive criticism where they felt it was needed, and working relationships have not been impaired by the process.

\section{Library director evaluation survey}

Please give your opinion of the director's activities by circling the number which is most appropriate. Use the following numbering system:

(1) none of the time, $0-20 \%$

(2) some of the time, $21-40 \%$

(3) half of the time, $41-60 \%$

(4) most of the time, $61-80 \%$

(5) all of the time, $81-100 \%$

(N) do not know or have no opinion.

Please explain your ratings wherever possible with examples of the director's decisions and actions that have led to your opinion. Write comments in the space provided after each question. Use additional sheets if necessary.

\section{Leadership in library operations}

The director:

1. Sees that library work is delegated to appropriate department heads.

2. Supports supervisors in the administration of their departments.

3. Requires that supervisors be fair and equitable in the administration of their departments. (Give examples of support or lack of support.)

4. Regularly checks with supervisors and staff to see that library work is progressing smoothly.

5. Provides recognition for outstanding individual accomplishments.

6. Provides constructive criticism when and where appropriate.

7. Acknowledges exemplary performance of library units.

8. Respects Library Faculty Bylaws and encourages collegiality in the operations of the library.

9 . Performs duties in a timely manner.

10. Acts quickly and decisively in resolving problems.

11. Sees that funds are fairly distributed and wisely spent.

12. Works to acquire additional funding through gifts, grants, etc.

13. Makes good decisions in the selection of new library faculty.

14. Successfully mediates conflicts and disputes within the library.

15. Sees that library disciplinary matters are handled fairly.

16. Handles merit raises fairly and equitably. 
17. Handles promotion and tenure fairly and equitably.

18. Promotes staff development.

19. Commands respect and confidence of the library staff.

\section{Communication}

The director:

1. Maintains an environment in which faculty and staff are encouraged to make suggestions for improving library operations.

2. Is available and cooperative when faculty have questions or problems to discuss.

3. Promotes candor and openness which allows free exchange of ideas (philosophy, professional issues, etc.) within the library.

4. Clearly delineates areas of responsibility to department heads.

5. Insures that existing channels of communication are used to transmit information from the administrative levels to library staff.

6. Insures that existing channels of communication are used to transmit information from library staff to appropriate administrative levels.

7. Insures that channels exist for sharing information between various library units.

\section{Leadership in identifying and achieving strategic goals}

\section{The director:}

1. Is successful in maintaining a staff and budget proportionate in size to the library's mission.

2. Produces and implements coherent plans which make the most efficient use of the library's personnel and material resources.

3. Effectively represents the needs, concerns and interests of the University Libraries to the UNR administration and other organizations that influence the library's development.

4. Has effectively involved library faculty committees in the strategic planning process.

5 . Has successfully directed the planning and development of the University Libraries to meet the challenges of growing enrollment and an increased university emphasis on research.

\section{Professional development}

The director:

1. Contributes to the growth of knowledge through publication, professional papers or other accepted vehicles.

2. Demonstrates awareness and understanding of current developments in librarianship and library management.

3 . Is appropriately active in university and community service.

4. Is appropriately active in statewide library activities.

Given your responses to the questions above and any other considerations you may wish to make (please specify below or on additional sheets of pa- per if necessary), what is your overall evaluation of the director? Use the rating system delineated in the Library Bylaws.

Circle one:

Unsatisfactory: The library director does not meet the demands of the position effectively or does not perform satisfactorily.

Satisfactory: The library director meets the demands of the position effectively and performs satisfactorily.

Commendable: The library director meets the objectives of the position in a manner which exceeds normal accomplishment and regularly produces good results.

Excellent: The library director consistently performs all aspects of the job in a clearly distinguished way, and consistently accomplishes outstanding results.

\section{Interview questions}

The Library Budget and Planning Committee and the Personnel Committee are conducting interviews with library faculty as the final step in the evaluation of the library director.

All library faculty are encouraged to take part in the interviews, but anyone may refuse to be interviewed if they so desire.

The interviews will:

a) Take 30 minutes or less.

b) Be confidential. Participants will not be identified by name.

c) Not be tape recorded. Notes will be taken of the interview session. At the end of the interview, the interviewer will summarize what was said, and the interviewee may, at this point, amend the statements.

1. Would you like to make any comments about any of the questions presented in the written sur-

\section{Reference materials awards}

The National Endowment for the Humanities Reference Materials program supports projects that organize essential resources for scholarship and improve access to information and collections. Awards are made in two categories: tools and access. Dictionaries, historical or linguistic atlases, encyclopedias, concordances, catalogues raisonnés, linguistic grammars, descriptive catalogs, and databases are eligible in the tools category. Archival arrangement and description projects, bibliographies, bibliographical databases, records surveys, cataloging projects, indexes, and guides to documentation are eligible in the access category. The new deadline for both categories is September 1,1989 , for projects beginning after July 1 , 1990. For more information, contact Reference Materials, NEH, Room 318, Washington, DC 20506. 
vey? Most people did not write any comments when they did the survey, and it would be helpful to have comments that explain why you rated the director as you did.

2. Please comment on areas of strength, accom- plishments or on other positive aspects of the director's performance.

3. Please comment on areas in which you feel the director needs to improve.

\title{
Academic library postcards, part II
}

\author{
By Billy R. Wilkinson \\ Director, Albin O. Kuhn Library \& Gallery \\ University of Maryland, Baltimore County
}

\section{Interior views of notable libraries.}

Editor's Note: In November 1988 we published the author's article on postcards with exterior views of academic libraries. He regaled us with a discussion of his and others' collections of cards ranging from pioneer cards to the contemporary. In this issue Billy Wilkinson, back by popular demand, holds forth on interior views. His future plans include an article on foreign library postcards, particularly if he is successful in obtaining a grant to study interiors of libraries in England. He is also peddling a bimonthly column to the media entitled "My Favorite Library Postcard."

Scarce, rare, even precious, might be the words to describe library postcards with views of interiors of academic libraries. In the author's November 1988 article in C $b R L$ News (pp. 646-651; please see for a general background on library postcards and those who collect them), a count of individual cards in two leading collections revealed that the largest number of cards of an academic library was 57 for the Low Library at Columbia University, in the author's collection of 5,205 library postcards. The Judith E. Holliday Collection had 38 Low Library cards. These are in contrast to the $158 \mathrm{New}$ York Public Library and 156 Boston Public Library cards gathered by the author and 48 NYPL and 75
Boston Public ones held by Holliday. In even greater contrast, both the Holliday and Wilkinson Collections have no interior views of that magnificent McKim, Mead and White building, the Low Library. How strange that the glorious marblecolumned Low Rotunda is missing in Postcard Land? Not even the Columbiana Room now in the Low Library has an interior card. Does anyone have a postcard with the Low Rotunda?

\section{Cornell and Yale Libraries}

What about interior views of the other academic libraries that are most numerous in the Holliday and Wilkinson Collections? The exterior of the 1890 Cornell University Library with its distinctive clock tower numbered 16 in the Holliday Collection and 41 in the Wilkinson Collection. There are no interiors in either collection! Not even of the triple-tiered Andrew Dickson White Historical Library, the scene of one of the murders in that delightful mystery, The Widening Stain, by W. Bolingbroke Johnson (pseudonym of Morris Bishop), which is set in the Cornell Library. Surely someone out there has a postal of the White Library?

Marjorie Markoff has a wonderful postcard of the main reading room of the Cornell Library showing readers at long tables with bentwood 